Portland State University

PDXScholar

Environmental Science and Management

Faculty Publications and Presentations

$10-2002$

\title{
Understory Species Patterns and Diversity in Old- Growth and Managed Northern Hardwood Forests
}

\author{
Robert M. Scheller \\ Portland State University, rmschell@pdx.edu \\ David J. Mladenoff \\ University of Wisconsin, Madison
}

Follow this and additional works at: https://pdxscholar.library.pdx.edu/esm_fac

Part of the Environmental Sciences Commons, Forest Sciences Commons, and the Plant Sciences Commons

Let us know how access to this document benefits you.

\section{Citation Details}

Robert M. Scheller and David J. Mladenoff 2002. UNDERSTORY SPECIES PATTERNS AND DIVERSITY IN OLD-GROWTH AND MANAGED NORTHERN HARDWOOD FORESTS. Ecological Applications 12:1329-1343.

This Article is brought to you for free and open access. It has been accepted for inclusion in Environmental Science and Management Faculty Publications and Presentations by an authorized administrator of PDXScholar. Please contact us if we can make this document more accessible: pdxscholar@pdx.edu. 


\title{
UNDERSTORY SPECIES PATTERNS AND DIVERSITY IN OLD-GROWTH AND MANAGED NORTHERN HARDWOOD FORESTS
}

\author{
Robert M. SchelleR ${ }^{1}$ And David J. Mladenoff \\ Department of Forest Ecology and Management, University of Wisconsin, Madison, Wisconsin, USA
}

\begin{abstract}
Forest management can significantly affect both the diversity and spatial patterning of understory vegetation. However, few studies have considered both diversity and spatial patterning at a stand scale. Our objective was to evaluate the effects of forest management on understory plant communities in northern hardwood forests and assess the processes governing differences in species composition, diversity, and spatial patterns. We sampled understory vegetation (all species $<2 \mathrm{~m}$ tall) and percentage of light transmission levels in three forest types in 12 mesic northern hardwood stands in northern Wisconsin and the Upper Peninsula of Michigan, USA: old-growth, undisturbed forests; even-aged forests resulting from clearcut logging ( $\sim 65-85 \mathrm{yr}$ old); and uneven-aged forests with recent selective logging.

Estimated understory species richness per stand, mean species richness per quadrat, and mean percent cover per quadrat were lower in old-growth forest than in even-aged, secondgrowth forests and lower in even-aged than in uneven-aged, second-growth forests. Differences in species composition among the three forest types were related to available light and to coarse woody debris; however, differences between the cover of most plant groups were not significant. The mean patch size of species diversity and cover is highly variable and could not be related to forest stand type. However, understory communities in oldgrowth forests have significantly smaller community patch sizes and larger compositional heterogeneity. Community patch size is correlated with both coarse woody debris and light heterogeneity. Each forest stand type produces a characteristic combination of understory composition, diversity, and spatial patterning of communities. Although harvesting has negligible effects on understory alpha diversity in these mesic hardwood forests, spatial structure is slower to recover and has not recovered in the even- and uneven-aged northern hardwood forests studied. If management objectives include preserving or restoring the ecological character of the forest, harvesting may need to be altered or delayed predicated on the character of the understory.

Key words: coarse woody debris; effects of logging; forest management; light; northern hardwood forests; plant diversity; spatial patterning; Sylvania Wilderness Area, Michigan, USA; understory vegetation.
\end{abstract}

\section{INTRODUCTION}

Since the 19th century, northern forests in the United States Lake States (Michigan, Minnesota, and Wisconsin) have been extensively altered and managed for human use (Mladenoff and Pastor 1993). Clearcutting of the primary forest was the prevalent form of timber harvest in northern Wisconsin until the early 20th century, causing significant alteration in both stand structure (Goodburn 1996) and landscape pattern (Mladenoff et al. 1993). The species composition, diversity, and spatial patterning of forest understory plants have also been altered as a result of logging and forest management (Duffy and Meier 1992, Keddy and Drummond 1996) with unknown consequences to community functioning (Berlow 1999).

Previous studies suggest that most understory species appear to be tolerant of overstory removal in northern

Manuscript received 26 February 2001; revised 8 January 2002; accepted 18 January 2002.

${ }^{1}$ E-mail: rmscheller@students.wisc.edu hardwood forests (Metzger and Schultz 1981, 1984, Hughes and Fahey 1991). In contrast, Appalachian hardwood forests may experience the reduction or extinction of many vernal herbs due to the slow colonization and recovery of many herbs, climate change, or the loss of necessary microsites (Duffy and Meier 1992, Meier et al. 1995). Uneven-aged management is a specific silvicultural treatment (Goodburn 1996) in which the effects on the forest understory may be comparable to any selective or partial harvesting. Similar to clearcutting, most studies have not found significant changes in overall community composition following selective logging (Metzger and Schultz 1984, Reader 1987, Reader and Bricker 1992, Jenkins and Parker 1999). However, vernal species may be more sensitive to uneven-aged management than clearcutting due to more frequent forest floor disturbance and desiccation caused by recurring periods of high radiation (Metzger and Schultz 1981).

Most studies of the effects of different forest management practices on understory plant species have been limited to an evaluation of the aggregate differ- 
ences in species richness and community composition within stands (Tonteri 1994, Goodburn 1996, Keddy and Drummond 1996), whereas the spatial patterning of understory communities and diversity has received less attention. Previously, most research on explicit spatial patterns (i.e., relative geographic location) of understory vegetation was performed at a fairly small scale, generally $<1$ ha (Struik and Curtis 1962, Crozier and Boerner 1984, Collins and Pickett 1987, Muller 1990, Houle 1998, Richard et al. 2000, Miller et al. 2002). However, understory communities may exhibit large-scale patterns within stands that are not evident or adequately sampled at these smaller scales. Because forest management occurs at the scale of a forest stand, it will be useful to quantify the effects of different management practices on the spatial pattern of understory communities at that scale.

The spatial patterning of understory vegetation may provide information about the nature, degree, and duration of the processes or resources that are structuring understory communities and help us to formulate hypotheses about the relevant processes (Dale 1999). Causes of spatial structure may include the provision of abiotic resources, such as soil water and nutrients (Robertson et al. 1993) and light (Nicotra et al. 1999), competition (Rogers 1985, Muller 1990), mortality (Janzen 1970), or establishment (Hubbell 1979, Houle 1998). Although spatial patterning can be used to make inferences about the processes affecting understory communities, it is often difficult, if not impossible, to establish causation between process and pattern in an ecological setting (Cale et al. 1989, Dale 1999).

The objective of this research was to elucidate the effects of forest management on understory communities in northern hardwood forests and to evaluate processes that may control these differences. We sampled understory vegetation (herbaceous plants, shrubs, and tree seedlings) and light at multiple scales (from $2 \mathrm{~m}$ to the extent of the forest stand, $\sim 0.5 \mathrm{~km}$ ) in three northern hardwood forest types: old-growth undisturbed forest, second-growth even-aged forest, and managed, uneven-aged second-growth forest. Oldgrowth forests were included as a comparison to the effects of human management. We hypothesized that species composition, diversity, and spatial patterns of understory vegetation would significantly differ between forests with different histories of human use. Furthermore, we hypothesized that understory vegetation in old-growth forests would be the most heterogeneous, due to the structural complexity of the canopy and coarse wood debris, but have the lowest species diversity due to a lack of early successional species. However, differences between even- and uneven-aged second-growth forests were difficult to predict. Specific questions addressed include: How do species composition, diversity, and abundance (cover) of the understory differ among the three forest stand types? How does the spatial pattern (patch size) of understory di-

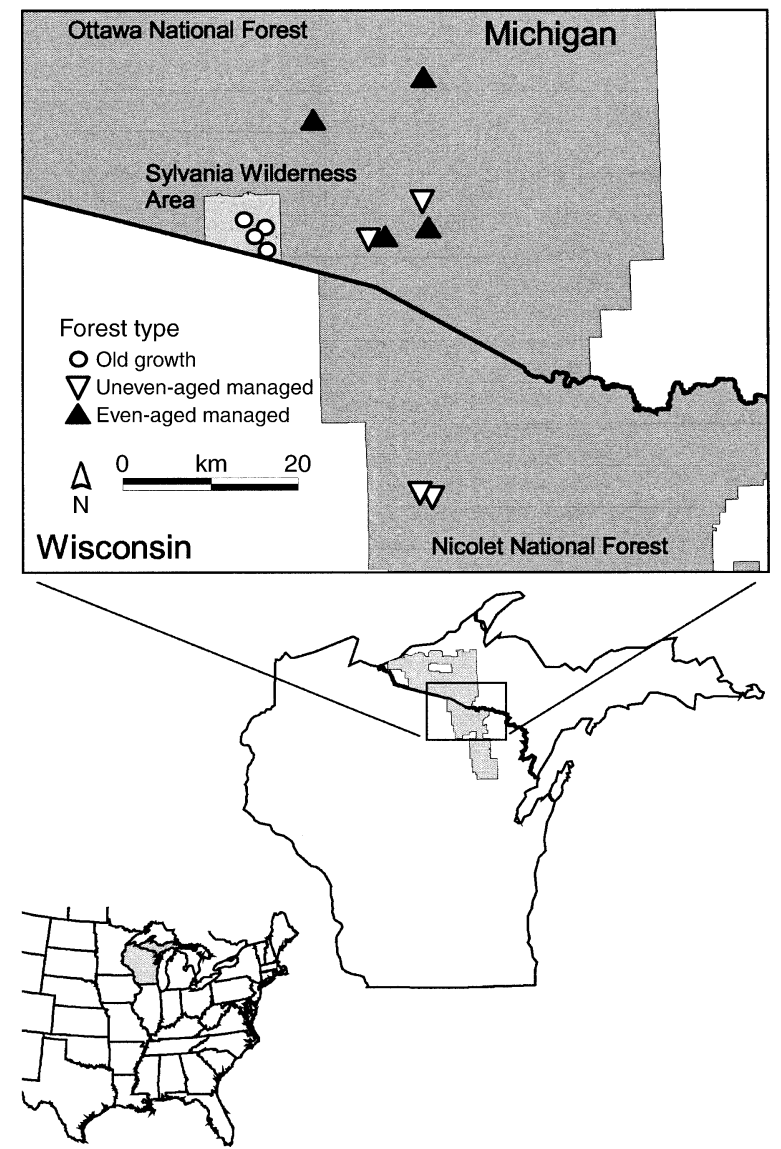

FIG. 1. Locations of 12 northern hardwood study sites in northern Wisconsin and Michigan, USA.

versity and cover differ among forest stand types using univariate measures? How does understory community spatial pattern (patch size and compositional heterogeneity) differ among forest stand types using multivariate measures? How are these quantitative measures of understory communities related to relevant plant resources, such as light and coarse wood debris?

\section{Methods}

Study area

Research was conducted in the Sylvania Wilderness Area $\left(\sim 89^{\circ} \mathrm{W}, 46^{\circ} \mathrm{N}\right.$; Fig. 1) and other areas of the Ottawa National Forest in Gogebic and Ontonagon Counties, Michigan, and the Nicolet National Forest in Forest County, Wisconsin, USA. The area is underlain by Laurentian shield bedrock and overlain with glacial deposits creating a gently rolling topography with elevations ranging from 517 to $567 \mathrm{~m}$ above mean sea level. Soil surface textures vary from coarse loamy to sandy (Table 1). The climate is continental with cold winters and mild summers. The growing season lasts from midMay through August, with an average frost-free period of $61 \mathrm{~d}$. Average annual precipitation is $864 \mathrm{~mm}$ with a mean of $420 \mathrm{~mm}$ within the growing season (Spies 
TABLE 1. Surficial geology and soils of 12 northern hardwood forest study sites in northern Wisconsin and Michigan, USA.

\begin{tabular}{|c|c|c|c|c|}
\hline Study site & Fragipan $\dagger$ & $\begin{array}{l}\text { Soil texture, } \\
\text { subgroup } \dagger\end{array}$ & Landform $\dagger$ & $\begin{array}{c}\text { Site } \\
\text { quality } \$\end{array}$ \\
\hline \multicolumn{5}{|l|}{ Old-growth } \\
\hline Sylvania 14 & no & sandy, Entic Haplorthod & ground moraine & low \\
\hline Sylvania 2 & yes & $\begin{array}{l}\text { coarse loamy, Alfic } \\
\text { Fragiorthod }\end{array}$ & $\begin{array}{l}\text { ice-contact } \\
\text { stratified drift }\end{array}$ & high \\
\hline Sylvania 6 & no & $\begin{array}{l}\text { coarse loamy, Typic } \\
\text { Haplorthod }\end{array}$ & outwash plain & medium \\
\hline Sylvania 9 & yes & $\begin{array}{l}\text { coarse loamy, Alfic } \\
\text { Fragiorthod }\end{array}$ & moraine & medium \\
\hline \multicolumn{5}{|l|}{ Even-aged } \\
\hline Coral Lake 2 & no data & sandy, Entic Haplorthod & moraine & no data \\
\hline Imp Lake 2 & yes & $\begin{array}{l}\text { coarse loamy, Typic } \\
\text { Fragiorthod }\end{array}$ & drumlin & medium \\
\hline Sucker Lake 2 & yes & $\begin{array}{l}\text { coarse loamy, Alfic } \\
\text { Fragiorthod }\end{array}$ & ground moraine & high \\
\hline Tamarack Lake 2 & no & $\begin{array}{l}\text { coarse loamy, Alfic } \\
\text { Haplorthod }\end{array}$ & ground moraine & medium \\
\hline \multicolumn{5}{|l|}{ Uneven-aged } \\
\hline Butternut North & no data & $\begin{array}{l}\text { coarse loamy, Alfic } \\
\text { Haplorthod }\end{array}$ & moraine & no data \\
\hline Butternut South & no & $\begin{array}{l}\text { coarse silty over sandy, } \\
\text { Alfic }\end{array}$ & outwash plain & medium \\
\hline Imp Lake 1 & no & $\begin{array}{l}\text { coarse loamy, Typic } \\
\text { Haplorthod }\end{array}$ & drumlin & medium \\
\hline Tamarack Lake 1 & yes & $\begin{array}{l}\text { coarse loamy, Alfic } \\
\text { Fragiorthod }\end{array}$ & ground moraine & high \\
\hline
\end{tabular}

$\dagger$ Sources: Bockheim (1997), J. G. Bockheim, unpublished data.

\$ Based on thickness and turnover of forest floor, condition of leaves, and presence/absence of A-horizon and earthworms/casts; site index for soil taxon from Vilas County soil survey report (J. G. Bockheim, unpublished data).

and Barnes 1985, Wisconsin State Climatology Office 1999).

Forest stands sampled were chosen from a larger set of 24 northern hardwood stands studied in a large, multidisciplinary project (Goodburn 1996, Bockheim 1997, Goodburn and Lorimer 1998, Miller et al. 2002). Four sites were randomly chosen within each of the three forest stand types, provided they each met the following criteria to the degree possible: a total stand area large enough to accommodate the sampling design, medium or high site quality (based on soil characteristics), and similar soil types (Table 1). These criteria severely limited the number of potential sites, and some variation in soil taxonomy, landform, and the presence or absence of a fragipan had to be accepted. Furthermore, we sought old-growth sites with no history of logging or other human disturbance and that were unfragmented (i.e., contained within a large contiguous area). Our criteria limited the available oldgrowth forests to the Sylvania Wilderness Area, which may create pseudoreplication (sensu Hurlbert 1984) and weaken any inferences drawn from this research, but there was no alternative. However, the size of the Sylvania Wilderness Area (>6000 ha) allowed us to place our sites between $\sim 2$ and $5 \mathrm{~km}$ apart and therefore reduce potential pseudoreplication to the extent possible. All 12 sites chosen had closed canopies domi- nated by sugar maple (Acer saccharum) with basswood (Tilia americana), yellow birch (Betula alleghaniensis), and eastern hemlock (Tsuga canadensis) as codominants. The relatively unmanaged, second-growth, even-aged forests resulted from clearcut logging in the early part of the last century ( 1916-1933) and are dominated by a canopy of relatively equal-sized trees. These even-aged forests have not been logged since the original clearcutting, although limited thinning or salvage cutting may have been performed. The managed uneven-aged forests have experienced relatively recent (1986 or 1988) harvesting under a single-tree selection system and are on a cutting cycle of 8-15 yr (Goodburn and Lorimer 1998). These stands contain a broad range of tree sizes and are managed under wildlife tree retention guidelines (Goodburn and Lorimer 1998). The long-term management history of these sites is generally unknown and a further potential source of variation, e.g., the long-term effects of uneven-aged management may not be fully reflected in the current stand conditions.

\section{Sampling design}

The sampling design was chosen to quantify the spatial patterns of understory vegetation within a forest stand from the scale of a $4.0-\mathrm{m}^{2}$ quadrat up to the scale (width) of the forest stand and to provide a reasonable 


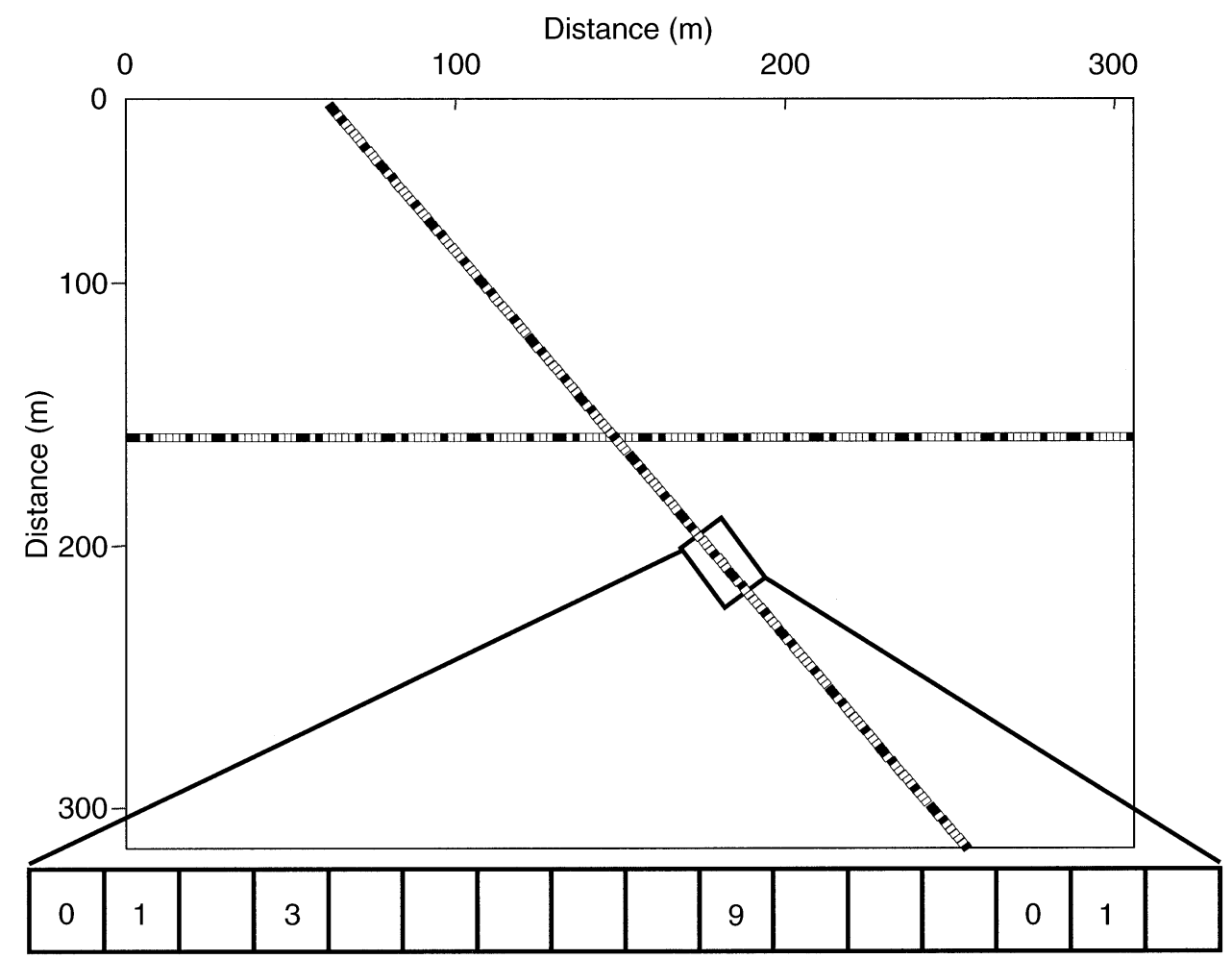

FIg. 2. Example of two transects overlapping at a $60^{\circ}$ angle. Full transects were $520 \mathrm{~m}$ in length. The 4 of 13 cyclic sampling is highlighted at the bottom, where each numbered box represents a $2 \times 2 \mathrm{~m}$ quadrat that was sampled. Note that each cycle begins and ends at quadrat 0 ; four quadrats were sampled in each 13 -quadrat cycle.

compromise between distance, statistical power, and detail (i.e., the amount of vegetation sampled). Understory vegetation was sampled along two transects of $4.0-\mathrm{m}^{2}(2 \times 2 \mathrm{~m})$ quadrats with a 4 of 13 cyclic sampling design (Clinger and Van Ness 1976, Clayton and Hudelson 1995; Fig. 2). By using unequally spaced quadrats in a repeating pattern, cyclical sampling both reduces sampling effort and provides spatial information at multiple scales, from $2 \mathrm{~m}$ to the length of the transect (Clinger and Van Ness 1976, Fortin et al. 1989, Miller et al. 2002). The two transects in each stand overlapped at a $60^{\circ}$ angle, providing additional distance pairs between transects and greater power for spatial statistics as determined by testing a variety of designs a priori. Each transect was a maximum of $520 \mathrm{~m}$ in length with 80 quadrats in 20 cycles (Fig. 2) as dictated by forest stands that were previously delineated for the multidisciplinary study. Transect lengths were adjusted to account for the variable size of the forest stands and to exclude non-forested areas (e.g., roads or swamps), forest edges, and seasonally flooded depressions. The total area sampled per stand ranged from 248 to $512 \mathrm{~m}^{2}$.

\section{Vegetation sampling}

All vascular plants $<2 \mathrm{~m}$ in height present within each quadrat were assigned a visual estimate of percent cover using a scale that emphasizes intermediate ac- curacy (Gauch 1982): 0.25, 0.5, 1, 2, 3, 4, 5, 10, 15, $20,30,40,50,60,70,80,90$, and 100\%. Gauch (1982) demonstrated that if the inherent variability (or "noise") of community samples is large relative to the variability introduced by sampling method, the aggregate error will increase marginally due to sampling error and high sampling accuracy is not necessary at all levels. The scale above also conforms to the recommendations of the Hatton et al. (1986) study of human error, which demonstrated that the range of percent cover from $20 \%$ to $70 \%$ should be given the least amount of accuracy although our scale extends this range to $100 \%$. Error was further reduced because only one individual estimated percent cover throughout the study and trained on artificial samples. Spring ephemerals were sampled once from mid-May to mid-June, 1999 or 2000 . The summer flora was sampled once from mid-June through August, 1998 or 1999.

\section{Environmental data}

Percentage of diffuse light transmittance ( $\% T$, sensu Nicotra et al. 1999), the proportion of total photosynthetically active radiation (PAR) reaching the understory vegetation, was collected at each quadrat using a Decagon AccuPAR ceptometer (Decagon 1999). Measurements at each stand were taken between 1000 and 1600 hours under uniformly cloudy conditions, once on a sin- 
gle day between July 1 and August 15, either 1999 or 2000. Measurements were taken above the tallest understory vegetation. Two measurements of PAR were recorded within $30 \mathrm{~s}$ of each other: within the forest stand at the quadrat (a mean of three measurements) and in a nearby opening that recorded open light conditions. The mean PAR at each quadrat was matched with the open canopy PAR with the nearest time stamp. Percentage of diffuse light transmittance was calculated as $\left(\mathrm{PAR}_{\text {forest }} / \mathrm{PAR}_{\text {open }}\right) \times 100$. Percentage of diffuse light transmittance was summarized at each site as the mean $\% T$ (MeanPAR), the quadrat variance of $\% T$ (VarPAR), and the percentage of quadrats either high light $(\% T>$ $5.0)$ or low light $(\% T<2.0$; HiLoPAR).

Total downed coarse woody debris (CWD) was sampled at 10 of the 12 sites as part of a previous study of the effects of forest management (Goodburn 1996, Goodburn and Lorimer 1998).

\section{Community composition analysis}

For each forest stand type, the data were summarized by species and by species group. The groups were created a priori and represent major life histories, growth habit types, and phenology: (1) ferns, (2) Lycopodia, (3) forbs (excluding 4 and 5), (4) spring ephemerals, (5) weedy species, (6) graminoids, (7) shrubs, and (8) trees (Goodburn 1996, Thomas et al. 1999). The groups generally do not strictly follow ecological guilds and are provided as a means to summarize the data and allow for comparisons with previous research. Ferns include both deciduous and evergreen species; lycopodia are woody and evergreen. Forbs are the broadest guild defined and consist of all herbaceous, flowering plant species (exclusive of graminoids and weedy species) that reach maximum size (percent cover) after leaf-out of the canopy trees. Spring ephemerals or vernal species are flowering plants that leaf out and reach maximum size before June 1 and senesce after canopy closure. Graminoids consist of all grasses and sedges. Shrubs are woody species not capable of reaching canopy or sub-canopy height. The weedy species category is the only group defined solely by ecological niche: these are forbs that are either invasive Eurasian exotics or aggressive natives associated with highly disturbed sites (Voss 1985, Scheller 2000).

We summarized individual species and groups by mean percent cover $(\Sigma$ mean percent cover for each stand/number of stands), mean frequency ( $\Sigma$ frequency for each stand/number of stands), and constancy (percentage of stands where occurring) for each forest stand type (old-growth, even-aged, uneven-aged). Mean percent cover and mean frequency were compared between forest types using Fisher's protected least significant difference (LSD) test at $\alpha=0.05$ (SAS 1999). Both percent cover and frequency were rank transformed before the ANOVA to correct for heteroscedasticity.

We chose nonmetric multidimensional scaling (NMS) ordination to provide an ecologically inter- pretable quantification of the compositional differences among forest types. Sørensen's coefficient, with species abundance measured as the species frequency at each stand, was used to calculate the community distance matrix for the 12 stands (Greig-Smith 1983). Frequency was chosen rather than cover due to the significant differences in cover among forest stand types. Uncommon species (those that occurred at 3 or fewer of the 12 sites) were deleted prior to ordination. These uncommon species did not occur at more than two sites in any given forest type and obfuscated the ecological interpretation of the axes. Species with an average frequency (across the 12 sites) below 0.05 were also deleted (McCune and Mefford 1999). The correlation between the ordination distances and distances in the original species space was used to estimate the amount of variance explained by each of the two axes (McCune and Mefford 1999). The axis scores from the ordination were subsequently regressed against stand-level environmental data; only significant correlations $(\alpha=0.05)$ are presented. Clustering of the three forest types was tested using a multi-response permutation procedure.

\section{Diversity and abundance analysis}

For the analysis of diversity and abundance, the 4.0$\mathrm{m}^{2}$ quadrat was considered the basic community unit within each stand. Species richness (number of species), Shannon's index (Greig-Smith 1983), and total cover ( $\Sigma$ percent cover of all species; henceforth simply "cover") were calculated for each quadrat. Mean richness $(S)$ per quadrat, mean Shannon's index $\left(H^{\prime}\right)$ per quadrat, and mean cover per quadrat were then calculated for each stand excluding all tree seedlings. Tree seedlings, particularly sugar maple seedlings, can suppress the other components of understory diversity and abundance and should be treated as an independent variable (Foster 1997, Miller et al. 2002). Total species richness at each site was estimated using a first-order jackknife estimator (Smith and van Belle 1984, Palmer 1990) as implemented in the free software EstimateS (Colwell 1997). The jackknife estimator corrects underestimates of species richness associated with the species-area curve (Palmer 1990). Differences among forest types were assessed with a Fisher's protected LSD test at $\alpha=0.05$ (SAS 1999) for the four measures of diversity or cover. Cover was rank transformed to correct heteroscedasticity prior to the ANOVA.

\section{Spatial pattern analysis of species diversity, cover, and PAR}

Spatial patterns of understory vegetation diversity, total cover, and percentage of transmittance $(\% T)$ were analyzed using the semivariogram and correlogram, for each of the 12 sites. Each method provides unique information about the spatial patterns (patch size and/or heterogeneity).

The semivariogram, a descriptive geostatistical tool, is used to estimate the patch size and patch heteroge- 
neity of explicit locational data (Legendre and Fortin 1989, Rossi et al. 1992, Goovaerts 1998).

The statistic used in the standard semivariogram is

$$
\gamma(h)=\frac{1}{2} \frac{\sum_{i=1}^{N(h)}[x(i)-x(i+h)]^{2}}{N(h)}
$$

where $h$ is a distance divisible by the lag (the stepsize); $x(i)=$ univariate measure at location $i$ (e.g., percent cover); $x(i+h)=$ univariate measure $h$ meters from the location of $x(i)$. If the distance between two points is not exactly equal to $h$, that distance pair is assigned to the closest bin (pool of distance pairs). Therefore, a bin contains $N(h)$ distance pairs. The semivariogram is half the averaged $(1 / 2 N[h])$ squared difference between every distance pair (Goovaerts 1998).

The semivariograms were modeled using a nonlinear minimization algorithm (Goovaerts 1998). Three functions were tested (linear, spherical, and Gaussian); the function with the lowest mean sum of squares, weighted by $N(h)$, was used to model the semivariogram. The nonlinear function is used to estimate the range (maximum distance of spatial dependence or patch size), the sill (total variance or the variance of the random field), and the nugget (inherent variance when distance is zero; Kaluzny et al. 1997). If the nonlinear minimization algorithm computed a range equal to the maximum distance of the semivariogram, this result was discarded as a spurious artifact caused by the inability of the algorithm to find a solution.

The correlogram is a geostatistical tool based on the semivariogram that is used to measure correlation as a function of distance (Goovaerts 1998, Rossi et al. 1992). The statistic for the correlogram is calculated as

$$
\rho(h)=1-\frac{\gamma(h)}{C(0)}
$$

where $C(0)$ is the finite variance of the random field (Kaluzny et al. 1997). A correlogram fit with a $90 \%$ confidence interval (Clayton and Hudelson 1995) was calculated for quadrat richness, Shannon's index, cover, and $\% T$. A locally weighted regression model or LOWESS curve $(\operatorname{span}=0.25$, degree $=1$; Trexler and Travis 1993, Kaluzny et al. 1997) was fit to the correlogram. A LOWESS curve models local or small-scale trends in the data and removes noise inherent in the correlogram (Kaluzny et al. 1997). The range of significant spatial autocorrelation is then calculated as the intersection of the LOWESS curve and the upper $90 \%$ confidence interval (Miller et al. 2002). The significant autocorrelation distance will generally be smaller than the semivariogram range because the LOWESS curve is more sensitive to local (small-scale) variations in the data. If the correlogram exhibits no significant autocorrelations, this information is used to reevaluate and possibly discard nonsignificant semivariogram ranges. Because the semivariogram emphasizes heterogeneity or variance and the correlogram emphasizes correlation, together they provide a complete picture of the spatial autocorrelation and its significance. The semivariogram and the correlogram are used in conjunction to evaluate both the range of spatial dependence and the significance of any spatial dependence measured.

\section{Spatial pattern analysis of understory communities}

The spatial patterning of understory communities may be expressed as the mean size of plant communities and the compositional difference between a community and the surrounding matrix of understory communities. Compositional difference is often dependent on spatial proximity: neighboring communities may be more similar than distant communities. For example, the forest understory could be composed of neighboring individual quadrats that contain very similar abundances of many of the same species (low compositional heterogeneity) or quadrats that contain entirely different species than the species found in nearby communities (high compositional heterogeneity). Neighboring quadrats with very similar composition define a larger community patch; the size of the patch (defined below) can be estimated in meters.

The sociogram (or "dissimogram"; Mistral et al. 2000) was used to quantify this spatial patterning (Scheller 2000). The sociogram utilizes Sørensen's coefficient to calculate the similarity of communities and geostatistical techniques to summarize the spatial patterns of communities (Scheller 2000). The sociogram is defined as

$$
\gamma_{s}(h)=\frac{1}{2 N(h)} \sum_{i=\alpha}^{N(h)} \mathrm{IA}-\frac{2 \sum_{1}^{j} \min \left[x(i)_{j}, x(i+h)_{j}\right]}{\sum_{1}^{j}\left[x(i)_{j}+x(i+h)_{j}\right]}
$$

where $h$ is a distance divisible by the lag (bins are used as with the semivariogram); IA is the internal association, the maximum value of percentage of similarity in the community matrix (Gauch 1982); $i$ is an individual quadrat (or community); $x$ is the percent cover in quadrats $(i)$ or $(i+h)$; and $j$ is the number of species in quadrats $x(i)$ or $x(i+h)$.

A function is fit to the data to estimate the range (mean community patch size), the effective sill (mean patch compositional heterogeneity), and the nugget (inherent dissimilarity) of the sociogram, similar to the semivariogram above. As with the semivariogram, the sociogram effectively measures spatial pattern at scales from the size of the quadrat $(2 \mathrm{~m})$ up to approximately half the maximum distance between quadrats.

The sociogram summarizes individual quadrat data to generate information about community patches that are compositionally similar. Specifically, the sociogram calculates the mean community patch size, mean patch compositional heterogeneity, and the inherent understory compositional dissimilarity. The mean commu- 
nity patch size (in meters) is the average geographic distance from the maximum between-quadrat self-similarity (usually at $0 \mathrm{~m}$ ) to the average geographic distance where between-quadrat dissimilarity is equal to global dissimilarity. Patch compositional heterogeneity is the measure of heterogeneity that exists above, or in addition to, the inherent dissimilarity. The inherent dissimilarity can be interpreted as sampling error and/or the overall random dissimilarity of communities (i.e., the minimum amount of dissimilarity we could expect between any two communities on average). In other words, patch compositional heterogeneity is a measure of how compositionally distinct the average community patch is from the surrounding mosaic of community patches (Scheller 2000).

\section{RESUlts}

\section{Understory composition and ordination}

In every plant group except spring ephemerals, mean percent cover and frequency were highest in the uneven-aged stands (Table 2). Differences were significant for percent cover in five plant groups (ferns, forbs, weeds, graminoids, and shrubs) and for frequency in two plant groups (graminoids and shrubs). Of the 128 plant species sampled in total, only 11 species were sampled exclusively in the old-growth stands, none of which is classified as rare or threatened by federal or state governments. Forty-one species (not including plants identified only to genus) were sampled only in even- or uneven-aged stands.

The NMS ordination included 38 species after rare or uncommon species were deleted and converged on two axes for the final solution (McCune and Mefford 1999). The ordination site scores exhibit a significant clustering of the three forest stand types $(P=0.02$; Fig. 3). Axis 1 explained $\sim 44 \%$ of the total variance; axis 2 explained an additional $40 \%$. Axis 1 is positively correlated with total downed CWD $\left(r^{2}=0.42, P=\right.$ 0.04; Fig. 4). The volume of total downed CWD is significantly higher in old-growth forests (Goodburn and Lorimer 1998). Axis 2 is positively correlated with both MeanPAR ( $r^{2}=0.38, P=0.03$; Fig. 5) and HiLoPAR $\left(r^{2}=0.55, P<0.01\right.$; Fig. 5$)$.

The species with the highest axis 1 scores included Lycopodium lucidulum, L. dendroidium (club mosses), Viola selkirkii, and Arisaema triphyllum (Fig. 3). Species with the lowest axis 1 scores included Erythronium americanum and Claytonia caroliniana (spring ephemerals) and Carex leptonervia, Carex spp., C. intumescens, and C. arctata (sedges) (Fig. 3).

The species with the highest axis 2 scores are generally associated with openings within northern hardwoods: Galium triflorum, Schizachne purpurescens, Rubus spp., Carex pensylvanica, and Sambucus spp. The species $G$. triflorum and $S$. purpurescens are found and persist in forest openings (Voss 1972, 1996). With the exception of Rubus hispidus, which can be easily distinguished by its trailing habit, and $R$. pubescens, which was identified separately from the remainder of the genus, Rubus spp. are early successional shrubs that favor clearings and high light conditions (Voss 1985). Species with low axis 2 scores are typical of low-light conditions: L. lucidulum, Gymnocarpium dryopteris, and the shrub Dirca palustris. E. americanum and $C$. intumenscens also have low axis 2 scores.

\section{Understory diversity and cover}

In all four nonspatial measures of diversity and abundance (estimated total species richness per stand, mean richness per quadrat, mean Shannon index per quadrat, and mean cover per quadrat), old-growth forests averaged lower than the even-aged forests, which averaged less than the uneven-aged forests. Estimated stand-level richness was significantly higher $(P=0.05$; Table 3 ) in uneven-aged than in old-growth forests. Uneven-aged forests also had significantly higher mean richness per quadrat than both old-growth and evenaged forests $(P=0.016)$. Mean Shannon diversity per quadrat did not show any significant effect due to forest stand type (ANOVA, $P=0.20$ ). Mean cover per quadrat was greatest in uneven-aged forests and least in oldgrowth $(P=0.02$; Table 3$)$. Cover is not closely correlated with diversity. Simple linear regressions of diversity on cover showed that only estimated richness had a significant, although weak, correlation with cover $\left(r^{2}=0.39, P=0.03\right)$.

\section{The spatial patterning of diversity and cover}

Contrary to understory diversity and cover, the within-stand spatial pattern of diversity and cover were not significantly different among forest stand types. The application of geostatistics to species richness, Shannon's index, and total cover provides a large amount of spatial information specific to each stand (Fig. 6). The semivariogram range was always greater than the significant correlogram range, often by an order of magnitude.

Not all stands exhibit spatial dependence in species richness. Three stands (one even-aged, two unevenaged) have the following qualities that indicate random patterning at scales larger than the individual quadrat: no significant spatial autocorrelation; the effective sill (total variance minus the nugget) of the semivariogram is small relative to the nugget (small scale variance at distance $=0$ ); and the variation of $\gamma(h)$ between adjacent distance lags is large (Scheller 2000). A similar analysis of spatial patterning reveals that Shannon's index has an apparently random distribution in 3 of the 12 stands, all within uneven-aged stands. The spatial dependence of total cover reveals that 5 of the 12 sites (two old-growth, two even-aged, and one uneven-aged) have no apparent spatial pattern (Fig. 6). Two stands, Coral Lake 2 (even-aged) and Imp 1 (uneven-aged), are randomly distributed for all measures of withinstand diversity and cover. 
TABLE 2. Individual species and plant group averages for three forest stand types in northern Wisconsin and Michigan, USA.

\begin{tabular}{|c|c|c|c|c|c|c|c|c|c|}
\hline \multirow[b]{2}{*}{ Species } & \multicolumn{3}{|c|}{ Old-growth } & \multicolumn{3}{|c|}{ Second-growth even-aged } & \multicolumn{3}{|c|}{ Managed uneven-aged } \\
\hline & $\begin{array}{c}\text { Percent } \\
\text { cover }\end{array}$ & Frequency & $\begin{array}{l}\text { Con- } \\
\text { stancy }\end{array}$ & $\begin{array}{c}\text { Percent } \\
\text { cover }\end{array}$ & Frequency & $\begin{array}{l}\text { Con- } \\
\text { stancy }\end{array}$ & $\begin{array}{c}\text { Percent } \\
\text { cover }\end{array}$ & Frequency & $\begin{array}{l}\text { Con- } \\
\text { stancy }\end{array}$ \\
\hline \multicolumn{10}{|l|}{ Ferns } \\
\hline Athyrium filix-femina & 0.07 & 9.91 & 100 & 0.46 & 14.83 & 100 & 1.51 & 39.51 & 100 \\
\hline Dryopteris intermedia & 1.42 & 58.37 & 100 & 2.24 & 50.09 & 100 & 4.24 & 73.56 & 100 \\
\hline Gymnocarpium dryopteris & 0.60 & 20.80 & 100 & 1.11 & 16.55 & 100 & 0.34 & 8.91 & 100 \\
\hline Osmunda claytoniana & 0.01 & 0.76 & 25 & 0.27 & 1.77 & 50 & 1.06 & 3.43 & 50 \\
\hline Thelypteris phegoptoris & 0.07 & 6.82 & 75 & 0.01 & 0.93 & 50 & 0.16 & 4.74 & 100 \\
\hline Total ferns & $2.28^{\mathrm{a}}$ & 69.15 & & $4.17^{b}$ & 64.20 & & $7.76^{\mathrm{c}}$ & 82.97 & \\
\hline \multicolumn{10}{|l|}{ Lycopodia } \\
\hline L. dendroideum & 0.29 & 10.97 & 100 & 0.12 & 7.66 & 75 & 1.03 & 16.44 & 75 \\
\hline L. lucidulum & 0.09 & 7.09 & 100 & 0.10 & 5.70 & 25 & 0.03 & 0.83 & 25 \\
\hline Total Lycopodia & 0.38 & 15.10 & & 0.22 & 12.41 & & 1.05 & 16.72 & \\
\hline \multicolumn{10}{|l|}{ Forbs } \\
\hline Actaea pachypoda & $\ldots$ & 0 & 0 & 0.00 & 1.16 & 50 & 0.02 & 2.81 & 50 \\
\hline Actaea spp. & 0.01 & 2.35 & 50 & 0.01 & 1.41 & 50 & 0.01 & 0.81 & 25 \\
\hline Anemone quinquefolia & 0.01 & 2.11 & 100 & 0.04 & 8.44 & 50 & 0.15 & 21.35 & 100 \\
\hline Aralia nudicaulis & 0.01 & 1.52 & 25 & 0.01 & 1.76 & 50 & 0.14 & 6.35 & 75 \\
\hline Arisaema triphyllum & 0.12 & 33.87 & 100 & 0.01 & 4.19 & 50 & 0.20 & 45.33 & 100 \\
\hline Aster macrophyllus & $\ldots$ & 0 & 0 & 0.01 & 2.59 & 75 & 0.07 & 5.98 & 75 \\
\hline Caulophyllum thalictroides & 0.00 & 0.72 & 50 & 0.03 & 1.94 & 50 & 0.09 & 6.31 & 75 \\
\hline Circaea alpina & 0.00 & 1.01 & 50 & $\cdots$ & 0 & 0 & 0.04 & 11.16 & 100 \\
\hline Clintonia borealis & $\ldots$ & 0 & 0 & 0.01 & 4.10 & 50 & 0.02 & 6.28 & 75 \\
\hline Galium triflorum & 0.01 & 2.98 & 75 & 0.00 & 0.51 & 25 & 0.12 & 25.53 & 100 \\
\hline Maianthemum canadense & 0.04 & 16.31 & 100 & 0.16 & 32.78 & 100 & 0.19 & 40.33 & 100 \\
\hline Mitchella repens & 0.00 & 0.39 & 25 & 0.00 & 0.56 & 50 & 0.00 & 1.49 & 50 \\
\hline Osmorhiza claytonii & 0.03 & 10.08 & 75 & 0.02 & 7.65 & 75 & 0.21 & 49.59 & 75 \\
\hline Oxalis acetosella & $\ldots$ & 0 & 0 & 0.00 & 0.57 & 50 & 0.01 & 1.80 & 75 \\
\hline Polygonatum pubescens & 0.06 & 19.73 & 100 & 0.06 & 19.90 & 100 & 0.07 & 23.79 & 100 \\
\hline Polygonum cilinode & $\ldots$ & 0 & 0 & 0.01 & 2.81 & 25 & 0.05 & 5.29 & 100 \\
\hline Scutellaria lateriflora & 0.01 & 3.28 & 75 & $\ldots$ & 0 & 0 & 0.00 & 0.36 & 25 \\
\hline Smilacina racemosa & 0.01 & 2.35 & 50 & 0.03 & 7.83 & 75 & 0.00 & 1.16 & 50 \\
\hline Streptopus roseus & 0.02 & 6.87 & 100 & 0.07 & 17.25 & 100 & 0.06 & 17.99 & 75 \\
\hline Trientalis borealis & 0.02 & 4.87 & 100 & 0.04 & 12.12 & 100 & 0.08 & 27.12 & 100 \\
\hline Trillium grandiflorum & 0.00 & 0.78 & 25 & $\ldots$ & 0 & 0 & 0.02 & 6.46 & 100 \\
\hline Trillium spp. & 0.00 & 1.22 & 50 & 0.02 & 6.49 & 50 & $\ldots$ & 0 & 0 \\
\hline Uvularia sessifolia & 0.00 & 1.39 & 50 & 0.00 & 0.77 & 75 & 0.01 & 2.02 & 25 \\
\hline Viola blanda & 0.02 & 6.38 & 75 & 0.09 & 11.65 & 75 & 0.31 & 42.21 & 100 \\
\hline Viola pubescens & 0.01 & 4.37 & 75 & 0.06 & 14.58 & 75 & 0.05 & 19.18 & 100 \\
\hline Viola selkirkii & 0.12 & 42.50 & 75 & 0.00 & 0.46 & 50 & 0.34 & 54.02 & 100 \\
\hline Viola spp. & 0.01 & 3.49 & 75 & 0.01 & 4.71 & 50 & $\cdots$ & 0 & 0 \\
\hline Total Forbs & $0.54^{\mathrm{a}}$ & 82.23 & & $0.79^{a}$ & 73.76 & & $2.32^{\mathrm{b}}$ & 97.01 & \\
\hline \multicolumn{10}{|l|}{ Spring ephemerals } \\
\hline Claytonia caroliniana & 0.10 & 24.72 & 75 & 1.91 & 66.59 & 75 & 0.34 & 41.94 & 75 \\
\hline Dentaria laciniata & 0.32 & 27.58 & 50 & 0.01 & 2.08 & 25 & 0.00 & 0.40 & 25 \\
\hline Erythronium americanum & $\ldots$ & 0 & 0 & 0.27 & 49.87 & 75 & 0.02 & 6.96 & 50 \\
\hline Total spring ephemerals & 0.84 & 53.06 & & 2.64 & 74.79 & & 0.61 & 52.38 & \\
\hline \multicolumn{10}{|l|}{ Weedy species } \\
\hline Galeopsis tetrahit & 0.01 & 1.95 & 50 & 0.07 & 12.62 & 25 & 5.13 & 32.88 & 75 \\
\hline Total weeds & $0.01^{\mathrm{a}}$ & 2.16 & & $0.08^{\mathrm{ab}}$ & 14.76 & & $5.14^{\mathrm{b}}$ & 34.45 & \\
\hline \multicolumn{10}{|l|}{ Graminoids } \\
\hline Brachyelytrum erectum & 0.03 & 4.21 & 100 & 0.06 & 16.46 & 100 & 0.12 & 17.07 & 100 \\
\hline Carex arctata & 0.02 & 3.49 & 75 & 0.05 & 12.82 & 100 & 0.05 & 10.72 & 100 \\
\hline Carex brunnescens & 0.00 & 0.97 & 50 & 0.00 & 0.42 & 25 & 0.01 & 2.14 & 25 \\
\hline Carex communis & 0.02 & 1.86 & 75 & 0.03 & 7.01 & 100 & 0.00 & 0.71 & 25 \\
\hline Carex deweyana & 0.02 & 4.72 & 100 & 0.02 & 7.66 & 75 & 0.04 & 4.98 & 75 \\
\hline Carex intumescens & 0.07 & 5.78 & 75 & 0.07 & 13.70 & 75 & 0.16 & 9.56 & 75 \\
\hline Carex leptonervia & 0.01 & 1.34 & 50 & 0.04 & 12.37 & 75 & 0.04 & 10.23 & 75 \\
\hline Carex pedunculata & 0.22 & 7.51 & 75 & 0.18 & 24.71 & 100 & 0.25 & 23.22 & 100 \\
\hline Carex pensylvanica & 0.12 & 6.28 & 75 & 0.02 & 4.14 & 75 & 3.56 & 38.98 & 75 \\
\hline Carex spp. & 0.02 & 2.57 & 75 & 0.03 & 9.29 & 100 & 0.02 & 6.85 & 100 \\
\hline Cinna latifolia & 0.02 & 4.64 & 50 & 0.02 & 6.43 & 75 & 0.09 & 19.02 & 100 \\
\hline Oryzopsis asperifolia & 0.02 & 1.80 & 75 & 0.14 & 20.16 & 100 & 0.65 & 25.86 & 100 \\
\hline Schizachne purpurescens & 0.02 & 1.36 & 75 & 0.01 & 4.51 & 75 & 0.20 & 15.72 & 100 \\
\hline Total graminoids & $0.57^{\mathrm{a}}$ & $31.00^{\mathrm{a}}$ & & $0.67^{\mathrm{a}}$ & $67.32^{b}$ & & $5.23^{\mathrm{b}}$ & $84.89^{b}$ & \\
\hline
\end{tabular}


TABle 2. Continued.

\begin{tabular}{|c|c|c|c|c|c|c|c|c|c|}
\hline \multirow[b]{2}{*}{ Species } & \multicolumn{3}{|c|}{ Old-growth } & \multicolumn{3}{|c|}{ Second-growth even-aged } & \multicolumn{3}{|c|}{ Managed uneven-aged } \\
\hline & $\begin{array}{l}\text { Percent } \\
\text { cover }\end{array}$ & Frequency & $\begin{array}{l}\text { Con- } \\
\text { stancy }\end{array}$ & $\begin{array}{c}\text { Percent } \\
\text { cover }\end{array}$ & Frequency & $\begin{array}{l}\text { Con- } \\
\text { stancy }\end{array}$ & $\begin{array}{c}\text { Percent } \\
\text { cover }\end{array}$ & Frequency & $\begin{array}{l}\text { Con- } \\
\text { stancy }\end{array}$ \\
\hline \multicolumn{10}{|l|}{ Shrubs } \\
\hline Cornus alternifolia & $\ldots$ & 0 & 0 & 0.01 & 2.57 & 50 & 0.01 & 1.52 & 50 \\
\hline Corylus cornuta & 0.12 & 0.89 & 50 & 0.00 & 0.56 & 50 & 0.02 & 1.21 & 25 \\
\hline Dirca palustris & 0.14 & 6.07 & 100 & 0.13 & 7.29 & 75 & 0.07 & 1.40 & 75 \\
\hline Prunus virginiana & $\ldots$ & 0 & 0 & 0.04 & 5.87 & 25 & 0.05 & 5.61 & 75 \\
\hline Ribes cynosbati & $\ldots$ & 0 & 0 & 0.00 & 1.01 & 50 & 0.02 & 5.10 & 100 \\
\hline Rubus spp. & 0.02 & 2.10 & 50 & 0.01 & 2.30 & 25 & 2.85 & 41.44 & 100 \\
\hline Sambucus spp. & 0.00 & 0.42 & 25 & 0.00 & 0.25 & 25 & 0.13 & 25.37 & 100 \\
\hline Total shrubs & $0.28^{\mathrm{a}}$ & $9.06^{\mathrm{a}}$ & & $0.16^{\mathrm{a}}$ & $13.77^{\mathrm{a}}$ & & $3.16^{\mathrm{b}}$ & $58.11^{\mathrm{b}}$ & \\
\hline \multicolumn{10}{|l|}{ Trees } \\
\hline Abies balsamea & 0.01 & 0.85 & 25 & 0.26 & 6.57 & 50 & 0.01 & 2.19 & 50 \\
\hline Acer saccharum & 8.62 & 97.89 & 100 & 6.92 & 98.42 & 100 & 14.62 & 90.28 & 100 \\
\hline Betula alleghaniensis & 0.01 & 3.36 & 75 & 0.01 & 1.99 & 50 & 0.06 & 10.84 & 100 \\
\hline Fraxinus americana & 0.01 & 2.79 & 50 & 0.01 & 2.23 & 25 & 0.13 & 17.06 & 75 \\
\hline Ostrya virginiana & 0.01 & 2.61 & 100 & 0.09 & 8.28 & 100 & 0.53 & 18.22 & 100 \\
\hline Prunus serotina & $\ldots$ & 0 & 0 & 0.12 & 24.91 & 100 & 0.23 & 26.54 & 100 \\
\hline Tilia americana & 0.00 & 1.19 & 50 & 0.01 & 1.85 & 50 & 0.01 & 4.38 & 75 \\
\hline Tsuga canadensis & 0.00 & 0.86 & 75 & $\ldots$ & 0 & 0 & 0.01 & 1.95 & 50 \\
\hline Unknown seedling & 0.01 & 2.11 & 50 & 0.01 & 1.37 & 50 & $\ldots$ & 0 & 0 \\
\hline Total trees & 8.67 & 97.51 & & 7.58 & 98.84 & & 15.71 & 95.83 & \\
\hline
\end{tabular}

Notes: Statistics include mean percent cover, mean frequency (percentage), and constancy (percentage of sites where found) for all species sampled at $>3$ sites. Superscript letters indicate significant differences among forest stand types (Fisher's protected LSD with $\alpha=0.10, N=4$ ). Both percent cover and frequency were rank transformed.

\section{Percentage of diffuse light transmittance}

Uneven-aged forests have significantly greater MeanPAR than both old-growth and even-aged forests (Table 4). Both the variance of $\% T$ and the percentage

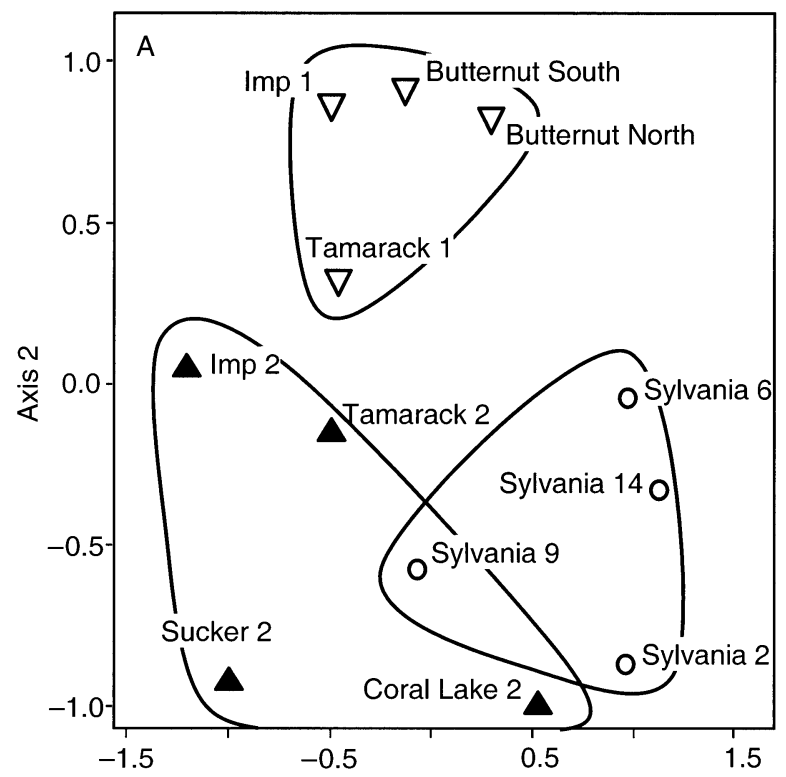

of quadrats with low light or high light differed significantly among forest types with even-aged the lowest and uneven-aged the highest (Table 4). Spatial dependence of $\% T$ is common in all three forest types (Fig.

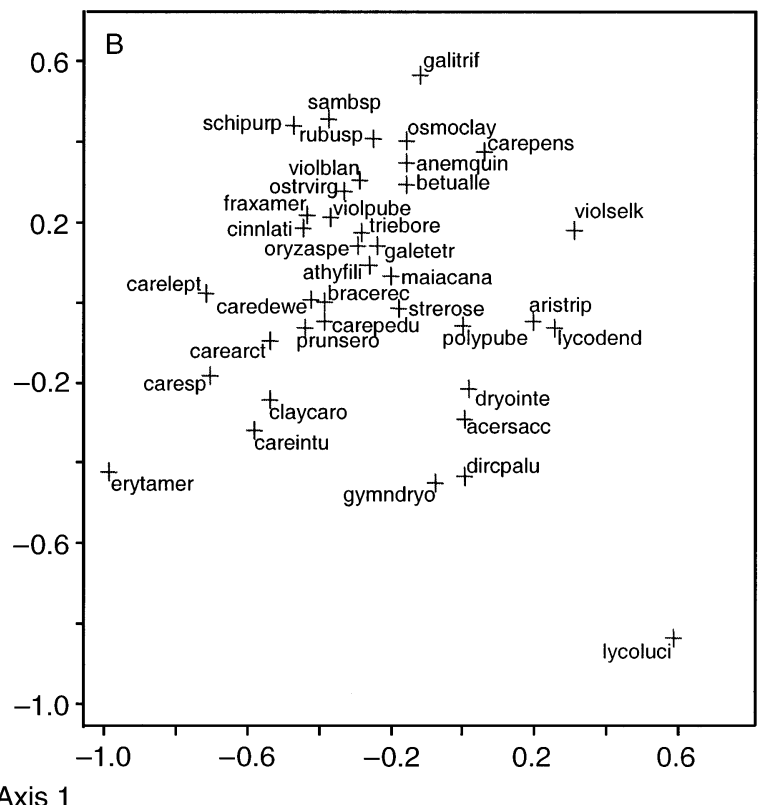

FIG. 3. Axes 1 and 2 from a nonmetric multidimensional scaling ordination of 12 northern hardwood sites using site frequency of species as abundance. Rare or uncommon (present at three or fewer sites) species were deleted. Symbols in panel (A) are: site ordination: old-growth = circle; even-aged = solid triangle; uneven-aged sites $=$ open inverted triangle. (B) Species ordination (species codes are created from the first four letters of the genus and species names; see Table 2). All units are raw axis scores. 


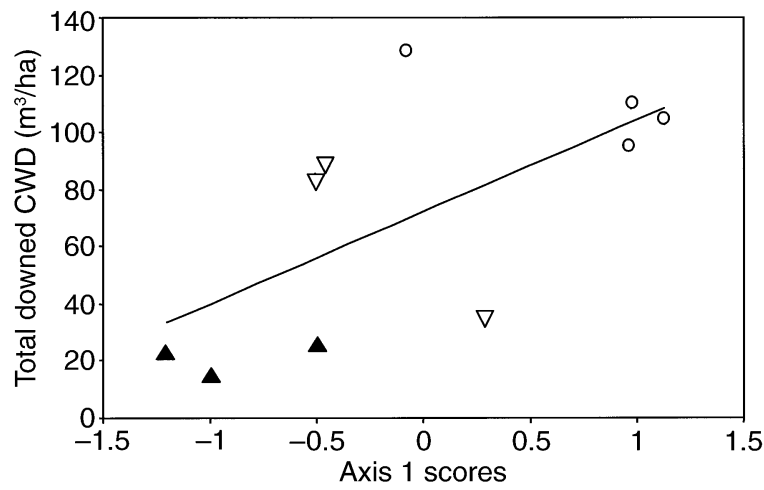

FIG. 4. Total downed coarse woody debris (CWD) regressed against raw axis 1 scores from the nonmetric multidimensional scaling ordination (Fig. 3). Old-growth = circle; even-aged $=$ solid triangle; uneven-aged sites $=$ open inverted triangle.

7), but neither the semivariogram range nor the significant correlogram range were significantly different among forest stand types (Fig. 7).

\section{Structural differences between forest understory} communities at within-stand scales

The sociogram quantified an approximately significant effect due to forest stand type in the patch size of

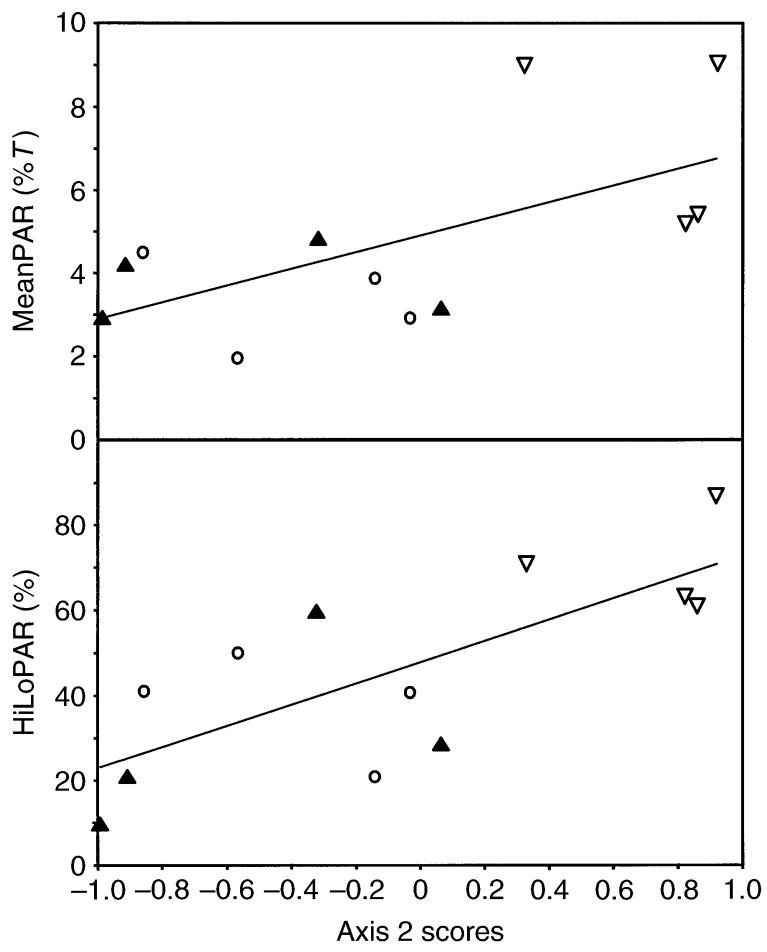

FIG. 5. Mean percentage of diffuse light transmittance (MeanPAR) and percentage of quadrats with either high light (percentage of diffuse light transmittance $[\% T]>5.0$ ) or low light $(\% T<2.0$; HiLoPAR $)$ regressed against raw axis 2 scores from the nonmetric multidimensional scaling ordination (Fig. 3). Old-growth = circle; even-aged = solid triangle; uneven-aged sites $=$ open inverted triangle.
TABLE 3. A summary of species diversity and abundance in 12 northern hardwood forests.

\begin{tabular}{lrcrcc}
\hline \hline Site & $N$ & $\begin{array}{c}\text { Estimated } \\
\text { richness }\end{array}$ & $\Sigma S / N$ & $\Sigma H^{\prime} / N$ & \multicolumn{2}{c}{$\Sigma$ Cover/ } \\
\hline Old-growth & & & & & \\
$\quad$ Sylvania 14 & 128 & 20.99 & 4.21 & 0.89 & 5.21 \\
Sylvania 2 & 117 & 54.70 & 2.90 & 0.68 & 3.93 \\
Sylvania 6 & 99 & 33.41 & 4.46 & 1.01 & 4.20 \\
$\quad$ Sylvania 9 & 66 & 30.05 & 5.52 & 1.15 & 6.40 \\
$\quad$ Mean & & $34.79^{\mathrm{a}}$ & $4.27^{\mathrm{a}}$ & 0.93 & $4.94^{\mathrm{a}}$ \\
Even-aged & & & & & \\
$\quad$ oral Lake 2 & 79 & 27.40 & 2.59 & 0.53 & 5.72 \\
Imp Lake 2 & 120 & 49.72 & 8.92 & 1.80 & 5.88 \\
Sucker Lake 2 & 101 & 47.42 & 6.06 & 1.12 & 13.40 \\
Tamarack & 100 & 43.06 & 8.48 & 1.33 & 12.52 \\
$\quad$ Lake 2 & & $41.93^{\mathrm{ab}}$ & $6.51^{\mathrm{a}}$ & 1.20 & $9.38^{\mathrm{b}}$ \\
Mean & & & & & \\
Uneven-aged & & & & & \\
Butternut & 88 & 50.81 & 8.02 & 1.25 & 25.77 \\
$\quad$ North & & & & & \\
Butternut & 90 & 52.05 & 11.82 & 1.42 & 47.60 \\
$\quad$ South & & & & & \\
Imp Lake 1 & 62 & 68.75 & 14.26 & 1.93 & 15.18 \\
Tamarack & 70 & 57.29 & 8.44 & 1.22 & 16.19 \\
$\quad$ Lake 1 & & & & & \\
Mean & & $57.23^{\mathrm{b}}$ & $10.64^{\mathrm{b}}$ & 1.46 & $26.37^{\mathrm{c}}$ \\
\hline
\end{tabular}

Notes: Statistics include number of quadrats sampled per stand $(N)$, estimated total species richness from a first-order jackknife estimator, mean species richness $(S)$ per quadrat, mean Shannon index $\left(H^{\prime}\right)$ per quadrat, and mean cover per quadrat. All analyses excluded sugar maple seedlings. Superscript letters indicate significant differences among forest stand types (Fisher's protected LSD with $\alpha=0.05$ ). Cover was rank transformed to correct for heteroscedasticity.

understory communities (Table 5). Mean old-growth patch size is significantly smaller than for both evenaged and uneven-aged sites. Community patch size in old-growth stands also exhibits less variation among stands than for either the even-aged or uneven-aged stands (Table 5). Although the mean patch compositional heterogeneity was larger in old-growth stands than in either even-aged or uneven-aged stands, the differences were not statistically significant. The inherent dissimilarity (nugget) was highly variable for all three forest types, and mean values are not significantly different.

\section{DISCUSSION}

Understory composition, diversity, and cover reflect forest management

The ordination, in conjunction with the environmental data, allows us to see how the species composition of the forest stand types are unique and significantly different. Although some of the site clustering found in the ordination (Fig. 3) may be due to geographic clustering (Fig. 1), this effect appears to be minimal. For example, the smaller uneven-aged cluster contains sites that are widely spaced geographically. Also, Coral Lake 2, which is clustered near old-growth forests in the ordination, is the most geographically distant even-aged site. 

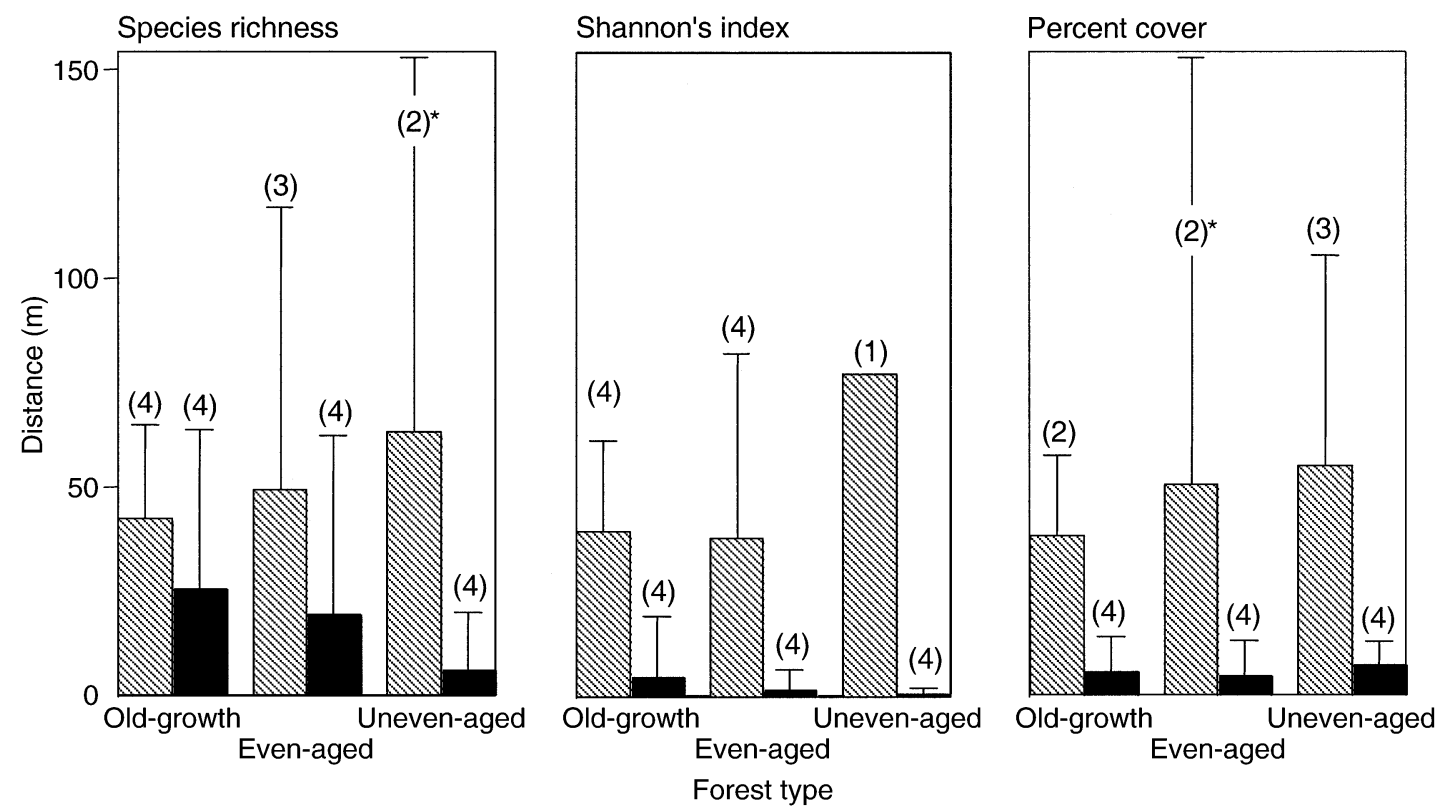

FIG. 6. Spatial pattern of abundance and diversity measures recorded for each quadrat in 12 northern hardwood forests (means and 95\% confidence intervals; an asterisk indicates the error bar is truncated). Numbers in parentheses above bars $=N$ for that class. The semivariogram range (hatched bars) and the correlogram range of significant autocorrelation (solid bars) are shown.

TABle 4. A summary of diffuse photosynthetically active radiation in 12 northern hardwood forests.

\begin{tabular}{lccc}
\hline \hline \multicolumn{1}{c}{ Site } & $\begin{array}{c}\text { Mean \%T } \\
\text { per quadrat }\end{array}$ & $\begin{array}{c}\text { Quadrat } \\
\text { variance } \\
\% T\end{array}$ & $\begin{array}{c}\text { Percentage of } \\
\text { quadrats high } \\
\text { or low light }\end{array}$ \\
\hline Old-growth & & & \\
$\quad$ Sylvania 14 & 4.75 & 8.00 & 59.4 \\
Sylvania 2 & 4.50 & 9.16 & 41.4 \\
Sylvania 6 & 2.95 & 3.18 & 40.4 \\
Sylvania 9 & 2.00 & 0.77 & 50.0 \\
Mean & $3.55^{\mathrm{a}}$ & $5.28^{\mathrm{ab}}$ & $47.7^{\mathrm{b}}$ \\
Even-aged & & & \\
Coral Lake 2 & 2.87 & 0.51 & 10.2 \\
Imp Lake 2 & 3.13 & 1.62 & 27.6 \\
Sucker Lake 2 & 4.20 & 1.40 & 20.8 \\
Tamarack Lake 2 & 3.84 & 1.66 & 21.0 \\
Mean & $3.51^{\mathrm{a}}$ & $1.30^{\mathrm{a}}$ & $19.9^{\mathrm{a}}$ \\
Uneven-aged & & & \\
Butternut North & 5.25 & 19.55 & 63.6 \\
Butternut South & 9.16 & 14.82 & 86.7 \\
Imp Lake 1 & 5.42 & 6.45 & 61.3 \\
Tamarack Lake 1 & 9.08 & 37.67 & 71.4 \\
Mean & $7.23^{\mathrm{b}}$ & $19.62^{\mathrm{b}}$ & $70.8^{\mathrm{c}}$ \\
\hline
\end{tabular}

Notes: Statistics include mean percentage of diffuse light transmittance $(\% T)$ per quadrat; quadrat variance of $\% T$; and the percentage of quadrats that had either high $(\% T>5.0)$ or low $(\% T<2.0)$ light conditions. Different superscript letters indicate significant differences among forest stand types (protected LSD with $\alpha=0.05$ ). Quadrat variance was rank transformed to correct for heteroscedasticity.
The ordination provides valuable information in addition to the clustering of the sites by species composition. There are two significant gradients correlated with light and CWD that together explain $>80 \%$ of the variation in species composition. Old-growth forests are correlated with low light and a high volume of CWD; even-aged forests with low light and a low vol-

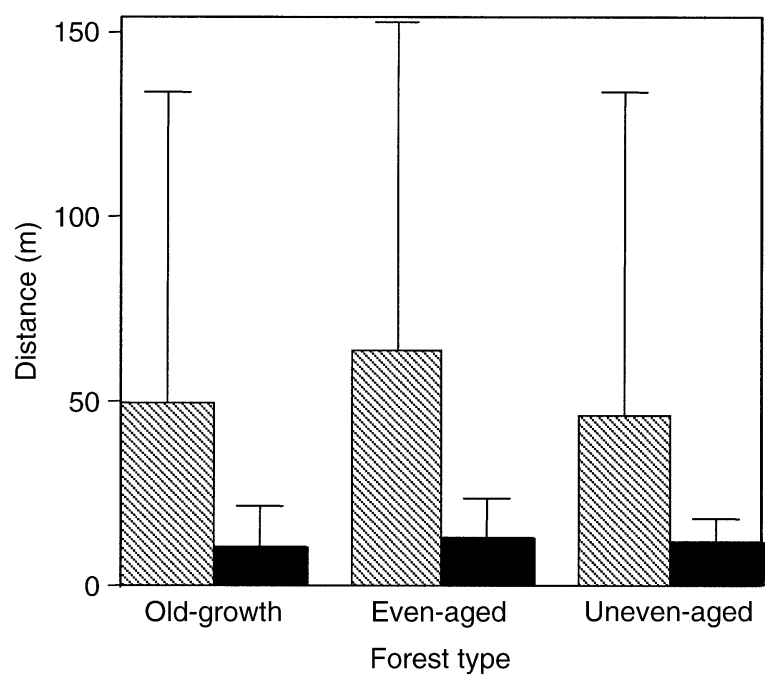

FIG. 7. Spatial pattern of percentage of photosynthetically active radiation ( $\% T$ ) recorded for each quadrat in 12 northern hardwood forests (means and 95\% confidence intervals; the even-aged semivariogram error bar is truncated). The semivariogram range (hatched bars) and the correlogram range of significant autocorrelation (solid bars) are shown. 
TABLE 5. Values for range, effective sill, and nugget from sociograms for 12 northern hardwood forests.

\begin{tabular}{|c|c|c|c|}
\hline Site & Range $\dagger$ & $\begin{array}{l}\text { Effective } \\
\text { sill } \$\end{array}$ & Nugget§ \\
\hline \multicolumn{4}{|l|}{ Old-growth } \\
\hline Sylvania 14 & 27.39 & 0.23 & 0.53 \\
\hline Sylvania 2 & 9.85 & 0.20 & 0.61 \\
\hline Sylvania 6 & 49.80 & 0.13 & 0.65 \\
\hline Sylvania 9 & 5.49 & 0.25 & 0.51 \\
\hline Mean (1 SE) & $23.13^{\mathrm{a}}(10.07)$ & $0.20(0.03)$ & $0.60(0.03)$ \\
\hline \multicolumn{4}{|l|}{ Even-aged } \\
\hline Coral Lake 2 & 93.60 & 0.12 & 0.68 \\
\hline Imp Lake 2 & 99.39 & 0.15 & 0.60 \\
\hline Sucker Lake 2 & 49.41 & 0.17 & 0.57 \\
\hline $\begin{array}{l}\text { Tamarack } \\
\text { Lake } 2\end{array}$ & 33.16 & 0.27 & 0.49 \\
\hline Mean (1 SE) & $68.89^{b}(16.32)$ & $0.18(0.03)$ & $0.59(0.04)$ \\
\hline \multicolumn{4}{|l|}{ Uneven-aged } \\
\hline $\begin{array}{l}\text { Butternut } \\
\text { North }\end{array}$ & 127.46 & 0.13 & 0.72 \\
\hline $\begin{array}{c}\text { Butternut } \\
\text { South }\end{array}$ & 26.52 & 0.26 & 0.45 \\
\hline Imp Lake 1 & 98.05 & 0.09 & 0.62 \\
\hline $\begin{array}{c}\text { Tamarack } \\
\text { Lake } 1\end{array}$ & 31.26 & 0.18 & 0.61 \\
\hline Mean (1 SE) & $70.82^{\mathrm{b}}(24.96)$ & $0.17(0.04)$ & $0.57(0.06)$ \\
\hline
\end{tabular}

Notes: Different superscript letters indicate significant differences among forest stand types (protected LSD with $\alpha=$ $0.10)$. Range was square-root transformed to correct for heteroscedasticity.

$\dagger F=2.86 ; \mathrm{df}=2,9 ; P=0.11$.

$\ddagger F=0.34 ; \mathrm{df}=2,9 ; P=0.72$.

$\S F=0.07 ;$ df $=2,9 ; P=0.93$.

ume of CWD; and uneven-aged forests with high light and a moderate volume of CWD. Species associated with CWD have high first axis scores and the first axis is significantly correlated to CWD. These species include Lycopodium dendroidium and L. lucidulum, which colonize nurse logs and rotten stumps (R. M. Scheller, personal observation), and Violet selkirkii, which is frequently found on tip-up mounds that are associated with downed CWD. Many shade-intolerant species have high second axis scores, and the second axis is positively correlated with MeanPAR and HiLoPAR. Conversely, the shade-tolerant, slow-growing species have low second axis scores. The two spring ephemerals with low axis 2 scores may have higher growth and reproduction when low light conditions suppress shade-intolerant species that often emerge in very early summer (R. M. Scheller, personal observation).

The largest differences in diversity and abundance were between old-growth forests and the uneven-aged, managed forests that receive periodic disturbance through selective logging. Our data show an increase in percent cover after selective cutting and the lowest diversity in undisturbed stands, similar to the differences between selection or group cutting and unharvested stands found by Metzger and Schultz (1984) in northern hardwood forests of Upper Michigan.
The resemblance we found between the diversity of old-growth and even-aged forests corroborates the findings of previous research that the effects of clearcutting on diversity are negligible after several decades (Albert and Barnes 1987, Gilliam et al. 1995, Halpern and Spies 1995, Ruben et al. 1999). Understory diversity peaks soon after disturbance followed by a long decline in diversity (Zamora 1982, Albert and Barnes 1987, Keenan and Kimmins 1993, Tonteri 1994). Our data contradict the loss of diversity due to logging found by Duffy and Meier (1992) and Meier et al. (1995) in Appalachian cove forests.

A possible explanation for the observed patterns of diversity and cover is that the slow-growing, shadetolerant species that characterize old-growth forests suppress the growth of many species and subsequently reduce richness and diversity. Foster (1997) also concluded that the early leaf-out of and deep shade cast by sugar maple seedlings and saplings limited the abundance of many herbs. This conclusion would support the intermediate disturbance hypothesis (IDH; Connell 1978). Although mature, even-aged forests have similar mean light levels (Table 4) and experience gap formation at a rate similar to old-growth forests (Goodburn 1996), they may contain many understory species that are remnant populations now at a competitive disadvantage and that may be reduced or eliminated over time. The IDH may also explain why diversity is greatest in uneven-aged stands: the disturbance is periodic and fairly recent (12-14 yr ago), and species composition is not dominated by slow-growing, shade-tolerant species.

\section{Understory diversity and communities display unique patch sizes and patch heterogeneity in different forest types}

The spatial analysis of species richness, Shannon's index, and total cover reveals that diversity and cover are often clumped in distribution. Species richness in our 12 stands was frequently clumped ( 9 of 12 sites) and cover less so ( 7 of 12 sites), the opposite of Muller's (1990) data that showed a uniform distribution of species richness and clumped distribution of species cover. Together, these spatial data suggest three conclusions: (1) within-stand spatial dependence is common for diversity and cover (mean richness per quadrat, mean Shannon's index, and mean total cover); (2) spatial dependence of diversity and cover is highly variable within stands, and there are no significant differences between forest types; and (3) some stands exhibit no spatial pattern at scales larger than the individual quadrat, which may indicate a nonequilibrium state (Wiens 1984, He et al. 1996). The cause of spatial dependence in diversity and abundance is difficult to assess. The scale of the spatial dependency is often large $(>50 \mathrm{~m})$ and is not likely related to the overstory canopy, which varies at much smaller scales.

The patchiness of diversity has important implica- 
tions for sampling understory vegetation. If the extent of vegetation sampling is less than the range of spatial autocorrelation, the estimate of richness and vegetation composition may be biased (Pielou 1966, Palmer 1987), and a correction may be necessary (Stohlgren et al. 1997). Only if the spatial extent of sampling extends beyond the range of diversity autocorrelation, conservatively estimated at $100 \mathrm{~m}$ based on our data, can a site be considered homogeneous in regard to diversity. Our estimates of total species richness using the first-order jackknife estimator met this criterion.

Understory communities, as measured by the sociogram, do have spatial structure that is significantly different between forest types. The sociogram successfully distinguished old-growth from even-aged and uneven-aged forests on the basis of understory community patch size. These differences in spatial structure between old-growth and second-growth (even- and uneven-aged) forests are separate from, and not congruent with, our previous comparisons of diversity that found significant differences primarily between old-growth and uneven-aged forests (Table 3 ). It is not clear why the spatial pattern of diversity and cover, measured with geostatistics, showed no significant forest type effect while the spatial pattern of communities, measured with the sociogram, was different among forest stand types. Multivariate measures of communities, such as the sociogram, integrate both diversity and abundance and therefore may better capture the spatial pattern of understory vegetation. Univariate measures of community, such as richness or cover, may not capture the relevant spatial pattern by themselves.

The differences in community spatial pattern between old-growth and even-aged forest stand types support our current understanding of forest succession. Important resources become more heterogeneous as closed-canopy forests (after stand initiation and selfthinning) mature, and this is reflected in the spatial patterning of the understory. Gaps, which create resource heterogeneity and perhaps subsequently understory heterogeneity (Moore and Vankat 1986, Collins and Pickett 1987, Chazdon 1988), are significantly smaller and gap density is lower in even-aged forests as compared to old-growth forests (Goodburn 1996). A significantly larger proportion of low- and high-light quadrats occurs in old-growth than in even-aged forests (Table 4) and reflects higher structural diversity. A similar pattern of light resources was found in old-growth and second-growth tropical forests in Costa Rica (Nicotra et al. 1999).

Clearcutting or selective logging may also reduce many of the historical legacies that create patchiness and heterogeneity. Coarse woody debris (CWD) is generally reduced in volume and size in the decades following clearcutting and will increase later with stand age (Tyrell and Crow 1994, Goodburn and Lorimer 1998). Goodburn and Lorimer (1998), working in many of the same northern hardwood forests that we studied, found that the volume of large-diameter $(>40 \mathrm{~cm})$ CWD is significantly different between all three forest types (old-growth $>$ uneven-aged $>$ even-aged). This apparent increase in resource heterogeneity from evenaged to old-growth may contribute to the decreased mean patch size and increased patch heterogeneity that we found in old-growth forest understory communities. When comparing the potential sources of resource heterogeneity measured, CWD was a better predictor of community patch size $(P=0.02)$ than was mean $\% T$ $(P=0.09)$.

The spatial patterning may also reflect species composition. However, our data do not support the hypothesis that the spatial structure we measured is related to community composition (Maslov 1989, Matlack 1994, Miller et al. 2002). Vegetatively reproducing species are closely associated with both old-growth and even-aged forests (Fig. 3), although these forests have a significantly different spatial structure.

\section{Management implications}

Our results indicate that clearcutting and selective logging have negligible effects on understory alpha diversity in these mesic hardwood forests, but the fundamental character of the species composition may be changed. Either a decrease in light levels or an increase in CWD, or both, may be necessary to recreate the original community. Specifically, if a management objective is to maintain ecological integrity, understory species should be evaluated before selective logging. If the understory is dominated by weedy or early successional species, either the volume of harvesting should be reduced or harvesting should be delayed.

In addition, an increase in CWD may be necessary to restore the spatial structure to preharvest levels. Increased community spatial structure (small patch size, greater patch heterogeneity) may be important to the maintenance of forest biodiversity for multiple reasons. Spatial structure may enhance the ecological stability of the system by spatially diversifying and diminishing interspecific competition in the understory community and preventing a unidirectional response to disturbance (May 1972, Frank and McNaughton 1991) or to predators (Ellner et al. 2001). Smaller understory patch sizes and larger patch heterogeneity may also provide enhanced structural diversity that is critical to small animals (Lidicker and Koenig 1996).

As uneven-aged management becomes the prevailing forest management system, both in Wisconsin and throughout the northern hardwood forests of the eastern United States, the structure and function of the understory vegetation may be altered at broad spatial scales. The risk to forest managers is that due to the periodic disturbances inherent to uneven-aged management, the unique structure and composition of such stands may represent not a transient state but a bifurcation to a new state characterized by weedy and early successional species. Conceivably, if light levels and soil distur- 
bance rates remain artificially high, these species may supplant sugar maple seedlings as the dominant competitor. In two of our uneven-aged sites (data not shown), Rubus spp. and/or Galeopsis tetrahit had clearly assumed the ecological niche of dominant competitor. Future research on the effects of forest harvesting on understory composition, diversity, and spatial patterning needs to address both long-term changes and the consequences of these changes at broad spatial scales.

\section{ACKNOWLEDGMENTS}

We are very grateful to Murray Clayton for statistical and sampling advice; David Spiering, Todd Miller, Ted Sickley, Caren Dymond, Jason McKeefry, and Barry DeZonia for field assistance; and members of the Forest Landscape Ecology Laboratory for their generous assistance and advice. Lisa Schulte and Janine Bolliger provided critical reviews of the manuscript. This project was funded by the Wisconsin Department of Natural Resources.

\section{Literature Cited}

Albert, D. A., and B. V. Barnes. 1987. Effects of clearcutting on the vegetation and soil of a sugar maple-dominated ecosystem, western Upper Michigan. Forest Ecology and Management 18:283-298.

Berlow, E. L. 1999. Strong effects of weak interactions in ecological communities. Nature 398:330-334.

Bockheim, J. G. 1997. Soils in a hemlock-hardwood ecosystem mosaic in the Southern Lake Superior Uplands. Canadian Journal of Forest Research 27:1147-1153.

Cale, W. G., G. M. Henebry, and J. A. Yeakley. 1989. Inferring process from pattern in natural communities. Can we understand what we see? BioScience 39:600-605.

Chazdon, R. L. 1988. Sunflecks and their importance to forest understory plants. Advances in Ecological Research 18:163.

Clayton, M. K., and B. D. Hudelson. 1995. Confidence intervals for autocorrelations based on cyclic samples. Journal of the American Statistical Association 90:753-757.

Clinger, W., and J. W. Van Ness. 1976. On unequally spaced time points in time series. Annals of Statistics 4:736-745.

Collins, B. S., and S. T. A. Pickett. 1987. Influence of canopy opening on the environment and herb layer in a northern hardwoods forest. Vegetatio 70:3-10.

Colwell, R. K. 1997. EstimateS. Version 5. User's guide and application. [Online, URL:〈http://viceroy.eeb.uconn.edu/ estimates $\rangle$.]

Connell, J. H. 1978. Diversity in tropical rain forests and coral reefs. Science 199:1302-1310.

Crozier, C. R., and R. E. J. Boerner. 1984. Correlations of understory herb distribution patterns with microhabitats under different tree species in mixed mesophytic forest. Oecologia 62:337-343.

Dale, M. R. T. 1999. Spatial pattern analysis in plant ecology. Cambridge University Press, Cambridge, UK.

Decagon. 1999. AccuPAR. Light interception device: operator's manual. Decagon Devices, Pullman, Washington, USA.

Duffy, D. C., and A. J. Meier. 1992. Do Appalachian herbaceous understories ever recover from clearcutting? Conservation Biology 6:196-201.

Ellner, S. P., E. McCauley, B. E. Kendall, C. J. Briggs, P. R. Hosseini, S. N. Wood, A. Janssen, M. W. Sabelis, P. Turchin, R. M. Nisbet, and W. W. Murdoch. 2001. Habitat structure and population persistence in an experimental community. Nature 412:538-543.

Fortin, M., P. Drapeau, and P. Legendre. 1989. Spatial au- tocorrelation and sampling design in plant ecology. Vegetatio 83:209-222.

Foster, D. K. 1997. Composition, structure, and diversity of forest understories along climatic and edaphic gradients in the Upper Great Lakes region. Dissertation. University of Wisconsin, Madison, Wisconsin, USA.

Frank, D. A., and S. J. McNaughton. 1991. Stability increases with diversity in plant communities: empirical evidence from the 1988 Yellowstone drought. Oikos 62:360-362.

Gauch, H. G. 1982. Multivariate analysis in community ecology. Cambridge University Press, New York, New York, USA.

Gilliam, F. S., N. L. Turrill, and M. B. Adams. 1995. Herbaceous-layer and overstory species in clear-cut and mature central Appalachian hardwood forests. Ecological Applications 5:947-955.

Goodburn, J. M. 1996. Comparison of forest habitat structure and composition in old-growth and managed hardwoods in Wisconsin and Michigan. Thesis. University of Wisconsin, Madison, Wisconsin, USA.

Goodburn, J. M., and C. G. Lorimer. 1998. Cavity trees and coarse woody debris in old-growth and managed northern hardwood forests in Wisconsin and Michigan. Canadian Journal of Forest Research 28:427-438.

Goovaerts, P. 1998. Geostatistical tools for characterizing the spatial variability of microbiological and physio-chemical soil properties. Biology and Fertility of Soils 27:315-334.

Greig-Smith, P. 1983. Quantitative plant ecology. University of California Press, Berkeley, California, USA.

Halpern, C. B., and T. A. Spies. 1995. Plant species diversity in natural and managed forests of the Pacific Northwest. Ecological Applications 5:913-934.

Hatton, T. J., N. E. West, and P. S. Johnson. 1986. Relationships of the error associated with ocular estimation and actual total cover. Journal of Range Management 39:9192.

He, F., P. Legendre, and J. V. LaFrankie. 1996. Spatial pattern of diversity in a tropical rain forest in Malaysia. Journal of Biogeography 23:57-74.

Houle, G. 1998. Seed dispersal and seedling recruitment of Betula alleghaniensis: spatial inconsistency in time. Ecology 79:807-818.

Hubbell, S. P. 1979. Tree dispersion, abundance, and diversity in a tropical dry forest. Science 203:1299-1309.

Hughes, J. W., and T. J. Fahey. 1991. Colonization dynamics of herbs and shrubs in a disturbed northern hardwood forest. Journal of Ecology 79:605-616.

Hurlbert, S. H. 1984. Pseudorepublication and the design of ecological field experiments. Ecological Monographs 54: 187-211.

Janzen, D. H. 1970. Herbivores and the number of tree species in tropical forests. American Naturalist 104:501-528.

Jenkins, M. A., and G. R. Parker. 1999. Composition and diversity of ground-layer vegetation in silvicultural openings of southern Indiana forests. American Midland Naturalist 142:1-16.

Kaluzny, S. P., S. C. Vega, T. P. Cardosa, and A. A. Shelly. 1997. S+ spatial stats. User's manual for Windows and UNIX. Springer, New York, New York, USA.

Keddy, P. A., and C. G. Drummond. 1996. Ecological properties for the evaluation, management, and restoration of temperate deciduous forest ecosystems. Ecological Applications 6:748-762.

Keenan, R. J., and J. P. Kimmins. 1993. The ecological effects of clear-cutting. Environmental Review 1:121-144.

Legendre, P., and M. Fortin. 1989. Spatial pattern and ecological analysis. Vegetatio 80:107-138.

Lidicker, W. Z., and W. D. Koenig. 1996. Responses of terrestrial vertebrates to habitat edges and corridors. Pages 85-109 in D. R. McCullough, editor. Metapopulations and 
wildlife conservation. Island Press, Washington, D.C., USA.

Maslov, A. A. 1989. Small-scale patterns of forest plants and environmental heterogeneity. Vegetatio 84:1-7.

Matlack, G. R. 1994. Plant species migration in a mixedhistory forest landscape in eastern North America. Ecology 75:1491-1502.

May, R. M. 1972. Will a large complex system be stable? Nature 238:413-414.

McCune, B., and M. J. Mefford. 1999. PC-ORD. Multivariate analysis of ecological data, version 4. MjM Software Design, Gleneden Beach, Oregon, USA.

Meier, A. J., S. P. Bratton, and D. C. Duffy. 1995. Possible ecological mechanisms for loss of vernal-herb diversity in logged eastern deciduous forests. Ecological Applications 5:935-946.

Metzger, F., and J. Schultz. 1981. Spring ground layer vegetation 50 years after harvesting in northern hardwood forests. American Midland Naturalist 105:44-50.

Metzger, F., and J. Schultz. 1984. Understory response to 50 years of management of a northern hardwood forest in Upper Michigan. American Midland Naturalist 112:209-223.

Miller, T. F., D. J. Mladenoff, and M. K. Clayton. 2002. Spatial autocorrelation and patterns of understory vegetation and environment in old-growth northern hardwood forests. Ecological Monographs 72, in press.

Mistral, M., O. Buck, D. C. Meier-Behrmann, D. A. Burnett, T. E. Barnfield, A. Scott, B. J. Anderson, and J. B. Wilson. 2000. Direct measurements of spatial autocorrelation at the community level in four plant communities. Journal of Vegetation Science 11:911-916.

Mladenoff, D. J., and J. Pastor. 1993. Sustainable forest ecosystems in the northern hardwood and conifer forest region concepts and management. Pages 141-180 in G. H. Aplet, N. Johnson, J. T. Olson, and V. A. Sample, editors. Defining sustainable forestry. Island Press, Washington, D.C., USA.

Mladenoff, D. J., M. A. White, J. Pastor, and T. R. Crow. 1993. Comparing spatial pattern in unaltered old-growth and disturbed forest landscapes. Ecological Applications 3 : 294-306.

Moore, M. R., and J. L. Vankat. 1986. Responses of the herb layer to the gap dynamics of a mature beech-maple forest. American Midland Naturalist 115:336-347.

Muller, R. N. 1990. Spatial interrelationships of deciduous forest herbs. Bulletin of the Torrey Botanical Club 117 101-105.

Nicotra, A. B., R. L. Chazdon, and S. V. B. Iriarte. 1999. Spatial heterogeneity of light and woody seedling regeneration in tropical wet forests. Ecology 80:1908-1926.

Palmer, M. W. 1987. Variability in species richness within Minnesota oldfields: a use of the variance test. Vegetatio 70:61-64.

Palmer, M. W. 1990. The estimation of species richness by extrapolation. Ecology 71:1195-1198.

Pielou, E. C. 1966. Species-diversity and pattern-diversity in the study of ecological succession. Journal of Theoretical Biology 10:370-383.

Reader, R. J. 1987. Loss of species from deciduous forest understory immediately following selective tree harvesting. Biological Conservation 42:231-244.

Reader, R. J., and B. D. Bricker. 1992. Value of selectively cut deciduous forest for understory herb conservation: an experimental assessment. Forest Ecology and Managemen 51:317-327.

Richard, M., T. Bernhardt, and G. Bell. 2000. Environmental heterogeneity and the spatial structure of fern species di- versity in one hectare of old-growth forest. Ecography 23: 231-245.

Robertson, G. P., J. R. Crum, and B. G. Ellis. 1993. The spatial variability of soil resources following long-term disturbance. Oecologia 96:451-456.

Rogers, R. S. 1985. Local coexistence of deciduous-forest groundlayer species growing in different seasons. Ecology 66:701-707.

Rossi, R. E., D. J. Mulla, A. G. Journel, and E. H. Franz. 1992. Geostatistical tools for modeling and interpreting ecological spatial dependence. Ecological Monographs 62: 277-314.

Ruben, J. A., D. T. Bolger, D. R. Peart, and M. P. Ayres. 1999. Understory herb assemblages 25 and 60 years after clearcutting of a northern hardwood forest, USA. Biological Conservation 90:203-215.

SAS. 1999. SAS/STAT user's guide, version 7. SAS Institute, Cary, North Carolina, USA.

Scheller, R. M. 2000. Forest understory diversity and spatial patterning in old-growth and managed northern hardwood forests in Wisconsin and Michigan. Thesis. University of Wisconsin, Madison, USA.

Smith, E. P., and G. van Belle. 1984. Nonparametric estimation of species richness. Biometrics 40:119-129.

Spies, T. A., and B. V. Barnes. 1985. A multifactor ecological classification of the northern hardwood and conifer ecosystems of Sylvania Recreation Area, Upper Peninsula, Michigan. Canadian Journal of Forest Research 15:949_ 960.

Stohlgren, T. J., M. B. Coughenour, G. W. Chong, D. Binkley, M. A. Kalkhan, L. D. Schell, D. J. Buckley, and J. K. Berry. 1997. Landscape analysis of plant diversity. Landscape Ecology 12:155-170.

Struik, G. J., and J. T. Curtis. 1962. Herb distribution in an Acer saccharum forest. American Midland Naturalist 68: 285-296.

Thomas, S. C., C. B. Halpern, D. A. Falk, D. A. Liguori, and K. A. Austin. 1999. Plant diversity in managed forests: understory responses to thinning and fertilization. Ecological Applications 9:864-879.

Tonteri, T. 1994. Species richness of boreal understorey forest vegetation in relation to site type and successional factors. Annual Zoological Fennici 31:53-60.

Trexler, J. C., and J. Travis. 1993. Nontraditional regression analyses. Ecology 74:1629-1637.

Tyrrell, L. E., and T. R. Crow. 1994. Structural characteristics of old-growth hemlock-hardwood forests in relation to age. Ecology 75:370-386.

Voss, E. G. 1972. Michigan flora. Part I. Gymnosperms and monocots. University of Michigan, Ann Arbor, Michigan, USA.

Voss, E. G. 1985. Michigan flora. Part II. Dicots. University of Michigan, Ann Arbor, Michigan, USA.

Voss, E. G. 1996. Michigan flora. Part III. Dicots concluded. University of Michigan, Ann Arbor, Michigan, USA.

Wiens, J. A. 1984. On understanding a non-equilibrium world: myth and reality in community patterns and processes. Pages 439-457 in D. R. Strong, Jr., D. Simberloff, L. G. Abele, and A. B. Thistle, editors. Ecological communities: conceptual issues and the evidence. Princeton University Press, Princeton, New Jersey, USA.

Wisconsin State Climatology Office. 1999. Historic climate summaries for Rhinelander, Wisconsin. Wisconsin State Climatology Office, Madison, Wisconsin, USA.

Zamora, B. A. 1982. Understory development in forest succession: an example from the inland northwest. Pages 6369 in J. E. Means, editor. Forest succession and stand development research in the Northwest. Oregon State University Press, Corvallis, Oregon, USA. 